\title{
Diversity and abundance of haptophytes in the East China Sea
}

\author{
Yun-Chi Lin', Chih-Ching Chung ${ }^{2,3}$, Gwo-Ching Gong ${ }^{2,3,4}$, Kuo-Ping Chiang ${ }^{1,2,3, *}$
}

\footnotetext{
${ }^{1}$ Institute of Environmental Biology and Fishery Science, National Taiwan Ocean University, Keelung 20224, Taiwan, ROC

${ }^{2}$ Institute of Marine Environmental Chemistry and Ecology, National Taiwan Ocean University, Keelung 20224, Taiwan, ROC ${ }^{3}$ Center of Excellence for the Oceans, National Taiwan Ocean University, Keelung 20224, Taiwan, ROC

${ }^{4}$ Taiwan Ocean Research Institute, National Applied Research Laboratories, Kaohsiung 85243, Taiwan, ROC
}

\begin{abstract}
Haptophytes (Prymnesiophytes) are important members of eukaryotic phytoplankton and therefore influence carbon and sulfur cycles in the marine ecosystem. The objective of this study was to investigate the distribution and taxonomic composition of haptophytes in the East China Sea (ECS). Our sampling area covered the ECS continental shelf in the spring and summer of 2009. An abundance of haptophytes was revealed by fluorescent in situ hybridization with an 18S rRNA-specific probe. A haptophyte blooming event reaching $2.2 \times 10^{4} \mathrm{cells} \mathrm{ml}^{-1}$ was observed in the Yellow Sea Mixing Water in spring. Phylogenetic analysis of the 18S rRNA gene revealed that the majority of this bloom was composed of Phaeocystis sequences that affiliated with $P$. jahnii and $P$. cordata. In contrast, in summer the assemblage composition of haptophytes was dominated by Chrysochromulina, with a maximum abundance of $3.1 \times 10^{3}$ cells ml $^{-1}$ occurring near the edge of the Changjiang Diluted Water. We also noted a relationship between larger size haptophytes and water eutrophication. The contribution of haptophytes to total nanoflagellate abundance at the ECS surface was $32 \%$ in spring and $12 \%$ in summer.
\end{abstract}

KEY WORDS: Haptophyte $\cdot$ Phaeocystis $\cdot 18 \mathrm{~S}$ rRNA gene

\section{INTRODUCTION}

Marine phytoplanktonic photosynthesis plays an important role in the global carbon cycle. It is known that eukaryotic phytoplankton contribute more than prokaryotic phytoplankton to biomass and primary productivity in small-size fractions (Worden et al. 2004). Eukaryotic phytoplankton comprise mainly Chlorophyta, Haptophyta, Heterokonta, Cryptophyta and Chlorarachniophyta (Vaulot et al. 2008), of which haptophytes (Prymnesiophytes) sometimes dominate in small-size fractions (cell size $<5 \mu \mathrm{m}$ ) based on quantitative data (Cuvelier et al. 2010, Masquelier et al. 2011). Also, an analysis of pigment composition and clone libraries suggests that haptophytes are important constituents of phytoplankton in the ocean (Not et al. 2008, Liu et al. 2009). Furthermore, Jardillier et al. (2010) reported that haptophytes are respon- sible for a significant percentage of the total carbon dioxide fixation in tropical and subtropical waters. However, the taxonomic composition of haptophytes is less well understood in marine ecosystems.

The haptophytes, which are mostly photosynthetic eukaryotes, are named for their unique haptonema used for attachment or capturing prey. The haptophytes, which include many famous taxa, such as Phaeocystis, Chrysochromulina and Prymnesium, play an important role in marine ecosystems due to their ability to form harmful and troublesome blooms. Phaeocystis is a cosmopolitan and well-known blooming genus of haptophytes, and tends to be more abundant in coastal waters at high latitudes (Schoemann et al. 2005). Their impacts on human economic activity include increased fish mortality, reduced shell fish reproduction and odorous foam on beaches (Lancelot \& Mathot 1987). The carbon 
fixed by Phaeocystis blooms can be exported to the deep sea or transferred to higher trophic levels via zooplankton predation (DiTullio et al. 2000, Schoemann et al. 2005). Moreover, Phaeocystis produces substantial amounts of dimethylsulfoniopropionate, the precursor of dimethylsulfide, which influences the global climate (Liss et al. 1994, Schoemann et al. 2005).

The hydrographic conditions of the East China Sea (ECS) are highly diverse and change with the seasons. During the spring of 2009, the Shelf Mixing Water (SMW) and the Yellow Sea Mixing Water (YSMW) were the main currents over the ECS shelf. The SMW, influenced by the Kuroshio flowing northward along the shelf edge of the ECS, was characterized as oligotrophic with high temperature $\left(>19^{\circ} \mathrm{C}\right)$ and high salinity (>33.7) (Fig. 1A). The YSMW, which occupied the northern ECS, was colder $\left(\leq 19^{\circ} \mathrm{C}\right)$ and more eutrophic than the SMW. The water masses of the ECS in summer consisted mainly of the Changjiang Diluted Water (CDW) and the Taiwan Current Warm Water (TCWW). The CDW occupied the north (salinity $\leq 31$ ) while the TCWW occupied the south (salinity >31) (Gong et al. 1996, Chiang et al. 2002) (Fig. 1A). Besides natural factors, the influence of human activity on the hydrography of the ECS should also be considered. The Changjiang River (also known as the Yangtze River), the longest river in China and the third longest in the world, injects large amounts of terrestrial nutrients and anthropogenic pollutants into the northern ECS (Dagg et al. 2004), to such an extent that eutrophic water often occupies the coastal waters of China, resulting in algal bloom events involving phytoplankton such as diatoms and dinoflagellates (Tang et al. 2006, Zhou et al. 2008, Gong et al. 2011).

Most studies on phytoplankton distribution in the ECS have involved pigment analysis, but few have focused on their abundances. The surveys on abundances of microphytoplankton (diatom) and prokaryotic picophytoplankton (Synechococcus) in the ECS indicate that their distribution patterns vary seasonally according to the dynamics of water masses (Chiang et al. 1999, 2002, Chung et al. 2014). Until now, no study has focused on the diversity and distribution of small eukaryotic phytoplankton in that area by using molecular techniques. Haptophytes are known as important contributors to carbon dioxide fixation in subtropical oceans (Jardillier et al. 2010), and also as important constituents in the phytoplankton community in the ECS according to pigment analysis (Furuya et al. 2003). However, little is known about their abundance, cell size and phylogenetic diversity in the ECS. In the present study, fluorescent in situ hybridization associated with tyramide signal amplification (FISH-TSA) targeting 18S rRNA was used to assess the distribution pattern of haptophytes in the ECS surface waters in the spring and summer of 2009. A haptophyte bloom was observed in the YSMW during spring. To discover the main bloom taxa, we first applied a haptophyte-specific probe to eukaryotic 18S rRNA gene clone libraries to acquire full-length 18S rRNA gene sequences. Haptophytespecific primers were also applied to amplify a shorter sequence of the 18S rRNA gene. To delineate the distribution patterns in bloom (spring) and nonbloom (summer) conditions, correlation analysis was performed between abundance and haptophyte cell size, and various environmental parameters. Profile data along the blooming transect was examined to aid our understanding of the vertical distribution of haptophytes and their requirements for nutrients and irradiance.

\section{MATERIALS AND METHODS}

\section{Sample collection and determination of hydrographic features}

Samples of surface water (2 to $3 \mathrm{~m}$ depth) were collected from onboard RV 'Ocean Researcher I' during the spring (29 April to 15 May) and summer (29 June to 13 July) of 2009. To understand the vertical distribution of haptophytes, water samples were collected from the surface down to near-bottom, or a depth of $100 \mathrm{~m}$, in the northern transect (Stns 19 to 24) during the spring cruise (Fig. 1B). Temperature and salinity data were acquired using conductivity, temperature, depth (CTD) instruments, SBE911 plus, (SeaBird), while water transparency and dissolved oxygen concentration were measured using additional sensors (Alphatracka II Transmissometer and SBE 43, respectively) attached to the CTD frame. Seawater was collected in 201 Niskin bottles mounted on a Rossette sampler equipped with a CTD profiler. Nutrients $\left(\mathrm{NH}_{4}, \mathrm{NO}_{2}, \mathrm{NO}_{3}, \mathrm{SiO}_{3}\right.$ and $\mathrm{PO}_{4}$ ) were measured in line with previous studies (Morris \& Riley 1963, Pai \& Yang 1990), but with some modifications (Gong et al. 1995). To determine chlorophyll a ( $\mathrm{chl} \mathrm{a)} \mathrm{concentration,} 1$ or 21 of seawater was filtered onto a $25 \mathrm{~mm}$ diameter GF/F filter (Whatman). After extraction, chl a was retained on the filter by acetone, and the concentration was determined with a fluorometer (Turner Designs) (Parsons et al. 1984). 


\section{Fluorescent in situ hybridization associated with tyramide signal amplification (FISH-TSA)}

Seawater samples (90 or $180 \mathrm{ml}$ ) for the FISH-TSA were preserved with formaldehyde (Sigma) at a final concentration of $3.7 \%$ for 1 to $24 \mathrm{~h}$. Cells in the fixative samples were subsequently collected on an $0.8 \mu \mathrm{m}$ pore size polycarbonate membrane $(47 \mathrm{~mm}$ diameter, Whatman) and stored at $-80^{\circ} \mathrm{C}$ until the FISH-TSA procedure. The FISH-TSA method was performed according to Not et al. (2002). In brief, the filters were hybridized with a horseradish peroxidase-labeled PRYM02 probe at a final concentration of $5 \mathrm{ng} \mathrm{hl}^{-1}$ in a hybridization buffer $(40 \%$ deionized formamide, $0.9 \mathrm{M} \mathrm{NaCl}, 20 \mathrm{mM}$ Tris- $\mathrm{HCl}, 0.01 \%$ sodium dodecyl sulfate [SDS], $2 \%$ blocking reagent [Roche Diagnostic Boehringer]) at $35^{\circ} \mathrm{C}$ for $3 \mathrm{~h}$. The PRYM02 probe (5'-GGA ATA CGA GTG CCC CTG AC-3') specifically recognizes the 18S rRNA in haptophyte cells (Simon et al. 2000) and can match $95 \%$ (22/466) of haptophytes from in silico analysis of both SILVA ARB database and our sequences. Nonhybridized probes were subsequently washed off with a washing buffer $(56 \mu \mathrm{M} \mathrm{NaCl}, 5 \mathrm{mM}$ EDTA, $0.01 \%$ SDS, $20 \mathrm{mM}$ Tris- $\mathrm{HCl}[\mathrm{pH} 7.5]$ ) at $37^{\circ} \mathrm{C}$ for 10 min twice. Signal amplification was performed in the amplification buffer containing Alexa488-tyramide at room temperature for $30 \mathrm{~min}$ in the dark. The membrane was observed with an epi-fluorescent microscope (Nikon Optiphot-2) after counterstaining cellular nuclei with 4',6-diamidino-2-phenylindole (DAPI) and mounting with a glycerol mixing antifading reagent AF3 (Citiñuor Ltd) (Porter \& Feig 1980).

\section{Microscopic counts of haptophytes and total nanoflagellates}

Abundances of haptophytes and total nanoflagellates $(\geq 2 \mu \mathrm{m}$, divided into heterotrophic and pigmented nanoflagellates) were estimated using different sections of the same filter. Counting of pigmented nanoflagellates excluded cell sizes of $<2 \mu \mathrm{m}$ due to extremely high values $\left(\sim 0^{5}\right.$ cells $\left.\mathrm{ml}^{-1}\right)$ in some eutrophic water in the ECS. Under excitation at a wavelength of $470 \mathrm{~nm}$ (blue), the FISH signals emit a green color. Haptophyte cell size was represented as equivalent spherical diameter, calculated from the length and width of a cell. The biovolume-carbon conversion for a eukaryotic phytoplankton was evaluated using $237 \mathrm{fg}$ carbon $\mu^{-3}$ (Worden et al. 2004).

\section{Phylogenetic analysis of 18S rRNA gene sequences}

The clone libraries for the18S rRNA gene were constructed at Stns 19, 23 and 12, representing eutrophic, mesotrophic and oligotrophic water, respectively (Fig. 1B). For DNA extraction, between 1.5 and $9.0 \mathrm{l}$ of seawater flowed through a $20 \mu \mathrm{m}$ nylon mesh, and was then pre-filtered through a $5 \mu \mathrm{m}$ pore size filter. Cells $<5 \mu \mathrm{m}$ were collected on a $0.8 \mu \mathrm{m}$ pore size filter. Genomic DNA was extracted by the phenol-chloroform method (Lin et al. 2012). The universal eukaryotic primers EUKA (5'-AAC CTG GTT GAT CCT GCC AGT A-3') and EUKB (5'GAT CCT TCT GCA GGT TCA CCT AC-3') were used in a PCR reaction to amplify the 18S rRNA gene (Medlin et al. 1988). The PCR conditions were as follows: $95^{\circ} \mathrm{C}$ for $2 \mathrm{~min}$, followed by 30 cycles of denaturing at $95^{\circ} \mathrm{C}$ for $45 \mathrm{~s}$, annealing at $55^{\circ} \mathrm{C}$ for $1 \mathrm{~min}$ and extension at $68^{\circ} \mathrm{C}$ for $2 \mathrm{~min}$, with a final extension step at $68^{\circ} \mathrm{C}$ for $10 \mathrm{~min}$. The subsequent cloning processes are described in Lin et al. (2012). We obtained about 50 successful eukaryotic sequences from each library for the full length of the 18S rRNA gene.

To comprehensively determine the assemblage composition of the haptophyte bloom observed in the spring of 2009, we used 2 methods to clarify the main bloom taxa. A haptophyte-specific probe was applied to 18S rRNA gene clone libraries to acquire full-length sequences. In addition, haptophyte-specific primers were used to amplify a shorter sequence of the 18S rRNA gene. Stn 16 was selected to study assemblage composition due to the abundance of haptophytes that occurred there $\left(10.3 \times 10^{3}\right.$ cells ml $^{-1}$; see Fig. 1E). About 400 colonies were randomly picked from the 18S rRNA gene libraries of both spring and summer samples. After disrupting cells with SDS, the plasmid DNA was transferred to nylon membranes (NEN Life Science Products) and hybridized with a digoxigenin (DIG) labeled PRYM02 probe. These colonies were recognized using alkaline phosphatase-conjugated anti-DIG antibodies (Roche) and reacted with substrate, CDP-Star, to produce a chemiluminescent signal. The signals were then detected by an imaging system (UVP Biospectrum) (Chung et al. 2003). Colonies with a positive signal were chosen for sequencing. For the Stn 16 samples, the universal eukaryotic primers Euk328f (5'-ACC TGG TTG ATC CTG CCA G-3') and Euk329r (5'-TGA TCC TTC YGC AGG TTC AC-3') were used in a PCR reaction to acquire full length 18S rRNA gene sequences (Moon-Van der Staay et al. 2000). The PCR conditions were as fol- 

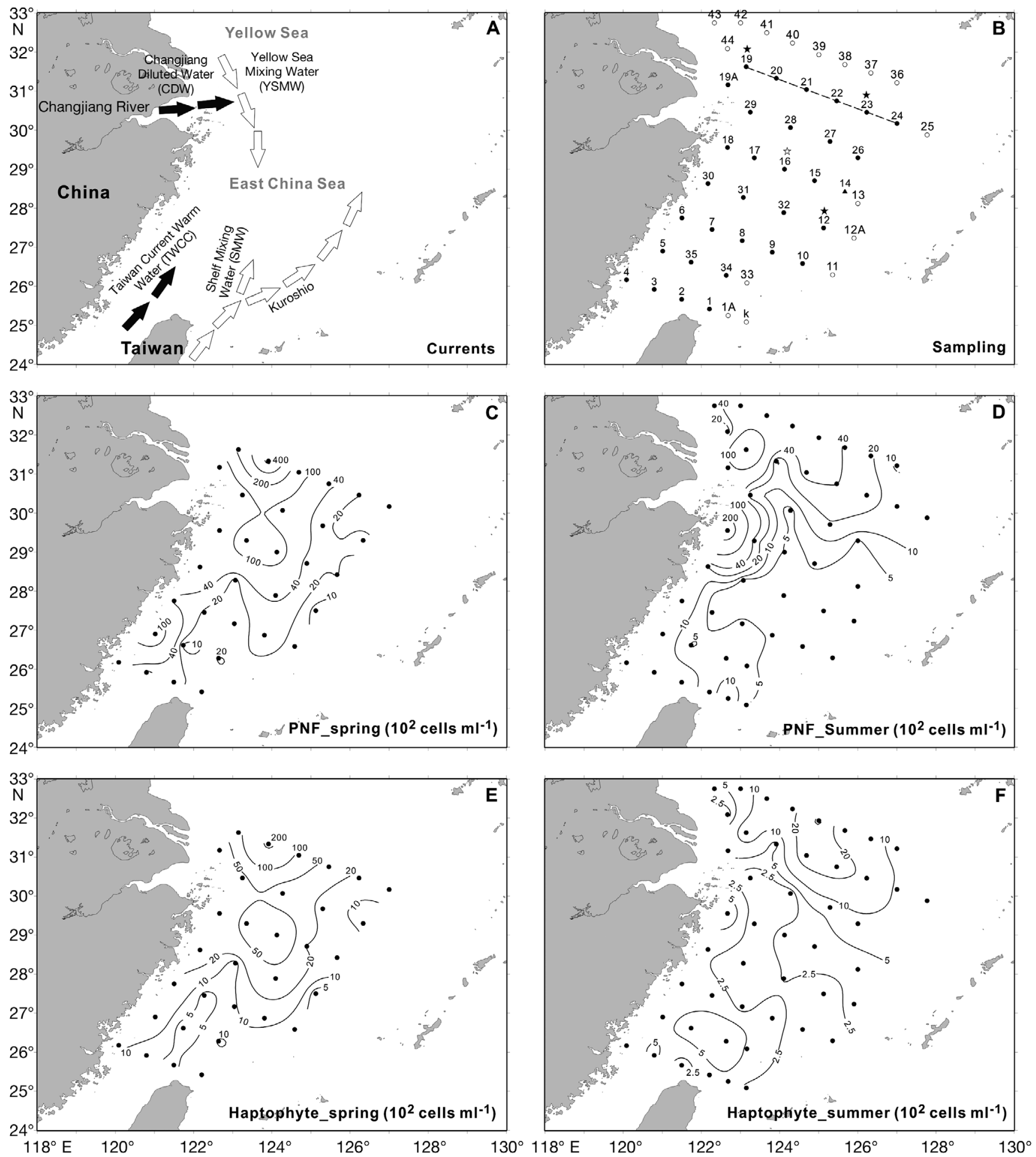

Fig. 1. (A) East China Sea (ECS) currents. The spring and summer currents are indicated with white arrows and black arrows, respectively. (B) ECS sampling stations. Surface abundance of haptophytes sampled in both spring and summer are indicated by filled circles. The open circles indicate stations sampled only in summer, while the triangle (Stn 14) indicates spring sampling only. The abundances of pigmented nanoflagellates and haptophytes were measured from surface water (depth of 2 to $3 \mathrm{~m} ; \mathrm{C}-\mathrm{F}$ ), except in the north transect of Stns 19 to 24 in spring (dashed line) where a vertical profile was determined. The stations marked with a filled star indicate sequences acquired from the cloning of all eukaryotes, while the station marked with an open star indicate acquisition from haptophytes only. Distribution patterns of $(C, D)$ pigmented nanoflagellates (PNF) and

$(\mathrm{E}, \mathrm{F})$ haptophytes in spring and summer $\left(10^{2}\right.$ cells $\left.\mathrm{ml}^{-1}\right)$. For the sake of clarity, the contour intervals are not equidistant 
lows: $95^{\circ} \mathrm{C}$ for $15 \mathrm{~min}$, followed by 32 cycles of denaturing at $95^{\circ} \mathrm{C}$ for $1 \mathrm{~min}$, annealing at $55^{\circ} \mathrm{C}$ for 2 min and extension at $72^{\circ} \mathrm{C}$ for $3 \mathrm{~min}$, with a final extension step at $72^{\circ} \mathrm{C}$ for $10 \mathrm{~min}$. A second approach used the haptophyte-specific primers Prym-429F (5'-GCG CGT AAA TTG CCC GAA-3') and Prym-887R (5'-GGA ATA CGA GTG CCC CTG AC-3') to amplify the 18S rRNA gene on PCR (Simon et al. 2000, Coolen et al. 2004) and its amplicon was $\sim 465 \mathrm{bp}$. The reverse primer Prym-887R is identical to the FISH probe of PRYM02. The touchdown PCR conditions consisted of 10 cycles of $94^{\circ} \mathrm{C}$ for $15 \mathrm{~s}, 60$ to $51^{\circ} \mathrm{C}$ for $30 \mathrm{~s}, 72^{\circ} \mathrm{C}$ for $2 \mathrm{~min}$, followed by 25 cycles of $94^{\circ} \mathrm{C}$ for $15 \mathrm{~s}, 55^{\circ} \mathrm{C}$ for 30 to $54 \mathrm{~s}$ and $72^{\circ} \mathrm{C}$ for $2 \mathrm{~min}$, with a final extension step of $72^{\circ} \mathrm{C}$ for $10 \mathrm{~min}$. Sanger's sequencing reaction was performed on a PRISM 3100 Genetic Analyzer (Applied Biosystems). Full-length 18S rRNA gene sequences were sequenced with 3 primers, 2 vector (T7 and SP6) and one internal (502f, 5'-GGA GGG CAA GTC TGG T-3') (Worden 2006), while partial sequences were sequenced with only one vector primer, T7.

All sequences were annotated against known sequences deposited in the GenBank database by the BLASTN algorithm (National Center for Biotechnology Information). A check for chimeric sequences was performed if the sequences had an identity $<98 \%$ against the known 18S rRNA sequences. Chimeric sequences were detected when annotations conflicted (at the order level) for different regions of an individual sequence (Massana et al. 2006), and were then excluded from further analysis. The sequences for phylogenetic analysis were edited and aligned with the ClustalW and Bioedit software. Phylogenetic trees were inferred from the neighbor-joining (NJ) and maximum likelihood (ML) methods, respectively, using 1000 and 100 bootstraps in PHYLIP 3.69 (Felsenstein 2005). The nucleotide substitution model for ML was selected by JModelTest with the Bayesian information criteria (Posada 2008). The haptophyte sequences reported in this paper have been deposited in the GenBank database under accession numbers KF620969 to KF621011 for full-length sequences and KJ608556 to KJ608631 for partiallength sequences.

\section{Statistical analysis}

The relationship between biological factors and their ambient environmental parameters were analyzed using Pearson's correlation (SPSS). Environmental parameters included temperature, salinity, nutrients $\left(\mathrm{NH}_{4}, \mathrm{NO}_{2}, \mathrm{NO}_{3}, \mathrm{SiO}_{3}\right.$ and $\left.\mathrm{PO}_{4}\right)$, transparency, dissolved oxygen and chl a concentration.

\section{RESULTS}

\section{Surface distribution of pigmented nanoflagellates and haptophytes}

The cell concentrations of pigmented nanoflagellates (PNF) and haptophytes at each station in the ECS are shown in Fig. 1C-F. Surface abundances of pigmented nanoflagellates varied from $5.6 \times 10^{2}$ to $4.3 \times 10^{4}$ cells ml $\mathrm{m}^{-1}$ in spring, and from $2.1 \times 10^{2}$ to $2.8 \times 10^{4}$ cells ml ${ }^{-1}$ in summer (Fig. $1 \mathrm{C}, \mathrm{D}$ ). For haptophytes, the range was from $1.5 \times 10^{2}$ to $2.2 \times 10^{4}$ cells $\mathrm{ml}^{-1}$ in spring and from $4.8 \times 10^{1}$ to $3.1 \times 10^{3} \mathrm{cells} \mathrm{ml}^{-1}$ in summer (Fig. 1, Table 1). The abundances showed similar distribution patterns in spring, but not in summer (Fig. 1). In spring, peak haptophyte abundance appeared in the northern transect of the ECS, which was occupied by the YSMW (Figs. 1E \& 2). A secondary peak of haptophyte abundance $\left(1.0 \times 10^{4}\right.$ cells $\mathrm{ml}^{-1}$ ) appeared at Stn 16 in the middle shelf (Fig. 1E). The high levels of haptophyte abundance $\left(>10^{4}\right.$ cells $\mathrm{ml}^{-1}$ ) indicated haptophyte bloom conditions in the northern region of the ECS in spring. In summer, peak haptophyte abundance occurred in the north-

Table 1. Comparison of environmental variables and haptophyte abundance in surface water at the stations for both spring and summer samples (filled circles in Fig. $1 \mathrm{~B} ; \mathrm{n}=31$ ). The table shows average values, standard deviations and ranges of these variables. A paired $t$-test was performed to judge the difference between the means of parameters between spring and summer and the results were considered significantly different at ${ }^{*} p<0.05,{ }^{* *} p<0.01$ or ${ }^{* * *} p<0.001$. The temperature and phosphate concentration were higher in summer while concentrations of chlorophyll $a$ and haptophytes were higher in spring

\begin{tabular}{|lcc|}
\hline Variable & Spring & Summer \\
\hline Temperature $\left({ }^{\circ} \mathrm{C}\right)$ & $19.4 \pm 2.3(15.7-25.3)$ & $26.6 \pm 1.5^{* * *}(23.3-28.8)$ \\
Salinity & $32.6 \pm 1.9(27.9-34.5)$ & $32.3 \pm 2.0(23.8-34.1)$ \\
$\mathrm{NH}_{4}(\mu \mathrm{M})$ & $1.0 \pm 0.7(0.1-3.0)$ & $0.8 \pm 0.6(0.25-2.5)$ \\
$\mathrm{NO}_{2}(\mu \mathrm{M})$ & $0.3 \pm 0.3(0-1.4)$ & $0.2 \pm 0.3(0-1.0)$ \\
$\mathrm{NO}_{3}(\mu \mathrm{M})$ & $3.2 \pm 5.9(0-25.3)$ & $2.2 \pm 5.7(0-24.3)$ \\
$\mathrm{PO}_{4}(\mu \mathrm{M})$ & $0.05 \pm 0.08(0-0.36)$ & $0.14 \pm 0.19 * *(0-0.83)$ \\
$\mathrm{SiO}_{3}(\mu \mathrm{M})$ & $6.4 \pm 6.3(0.9-28.7)$ & $6.1 \pm 6.2(1.5-24.5)$ \\
$\mathrm{Chlorophyll}\left(\mathrm{mg} \mathrm{m}^{-3}\right)$ & $1.96 \pm 2.47^{*}(0.24-10.96)$ & $1.14 \pm 1.40(0.14-5.1)$ \\
Haptophyte $\left(10^{2} \mathrm{cells} \mathrm{ml}^{-1}\right)$ & $30.9 \pm 43.7^{* *}(1.6-223.9)$ & $6.1 \pm 6.7(0.5-27.6)$ \\
\hline
\end{tabular}




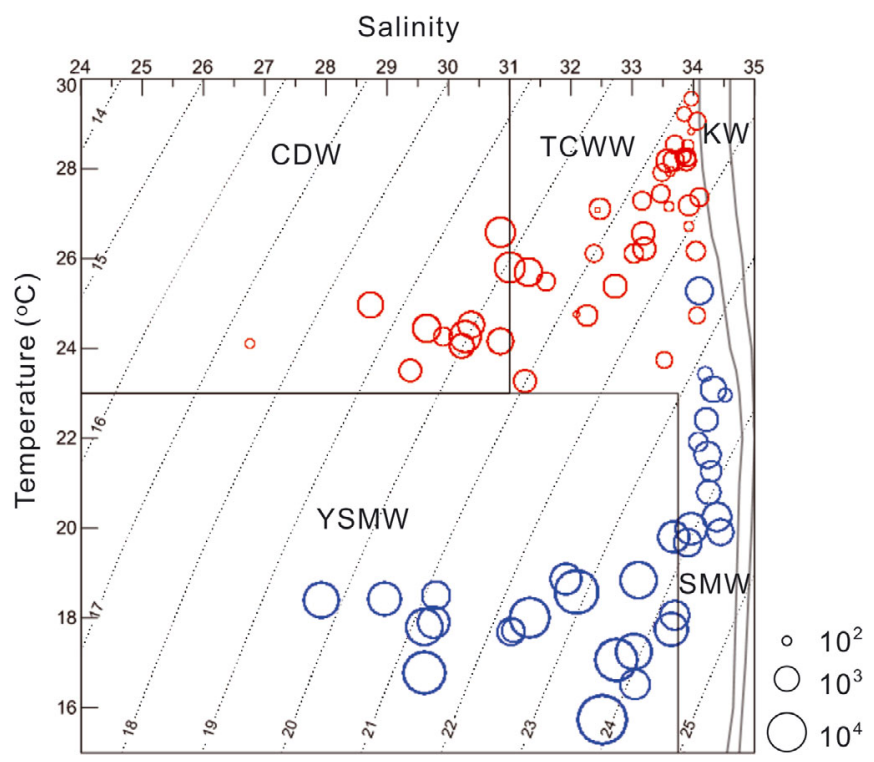

Fig. 2. Surface abundance of haptophytes obtained by the fluorescent in situ hybridization method in the East China Sea (circle size, $\log _{10}$ [haptophyte abundance, cells $\mathrm{ml}^{-1}$ ]) coupled with temperature and salinity. The grey parallel lines represent $\sigma_{\theta}$. The spring samples (blue) were characterized by Yellow Sea Mixing Water (YSMW) and Shelf Mixing Water (SMW), and the summer samples (red) were characterized by Changjiang Diluted Water (CDW) and Taiwan Current Warm Water (TCWW). The area between the gray curves represents the Kuroshio Water (KW). All data were acquired from surface water ern ECS at the edge of the CDW (Figs. 1F \& 2). Generally, there was a low abundance of haptophytes $\left(<1 \times 10^{3}\right.$ cells $\left.\mathrm{ml}^{-1}\right)$ in the southern ECS and offshore area in spring, and also outside the northern plume area in summer (Fig. 1E,F). The average abundance of haptophytes in spring and summer was about $3 \times 10^{3}$ cells $\mathrm{ml}^{-1}$ and $6 \times 10^{2}$ cells $\mathrm{ml}^{-1}$, respectively (Table 1). The abundance of haptophytes was higher in spring than in summer (paired $t$-test, $\mathrm{p}<0.001$; Table 1). Overall, haptophytes contributed $52 \%$ and $49 \%$ to pigmented nanoflagellates, and $32 \%$ and $12 \%$ to total nanoflagellates abundances (cells $\mathrm{ml}^{-1}$ ) in spring and summer, respectively.

\section{Vertical distribution of haptophytes along the cross-shelf transects during the bloom}

A haptophyte bloom was observed in the YSMW during the spring period (Fig. 1E). A vertical profile along the transect of Stns 19 to 24 showed that fresh water from the Changjiang was visible at Stn 19, whereas the more saline water of the YSMW occupied Stns 20 to 23 (Fig. 3). The haptophyte abundance peaked at the boundary of the coastal mixing water and oceanic water (Fig. 3). At Stns 19 to 22,
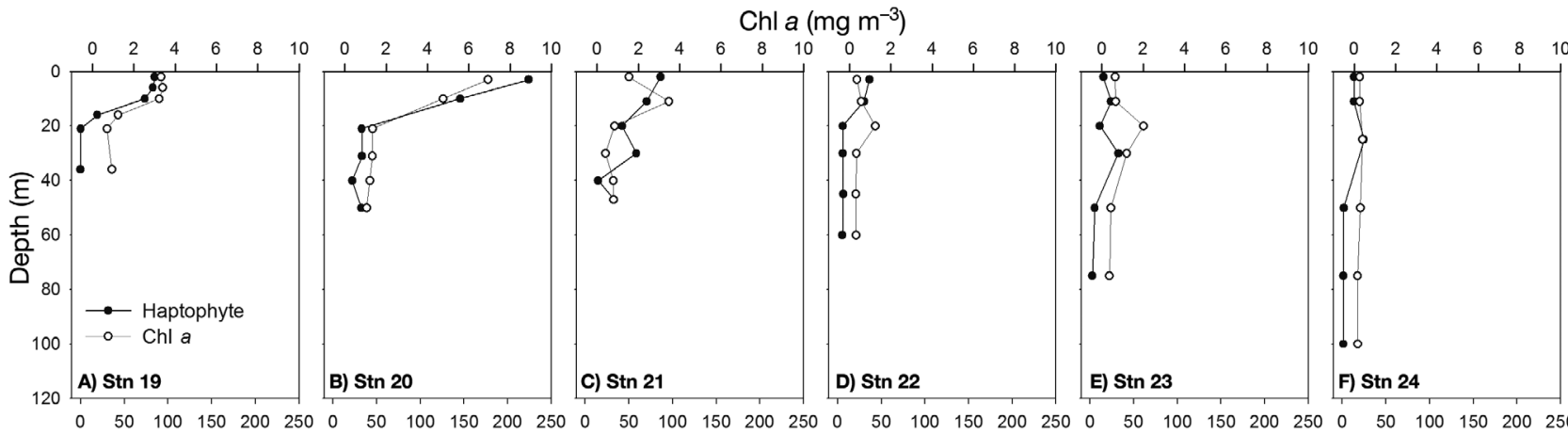

Haptophyte $\left(10^{2}\right.$ cells $\left.^{-1}\right)$
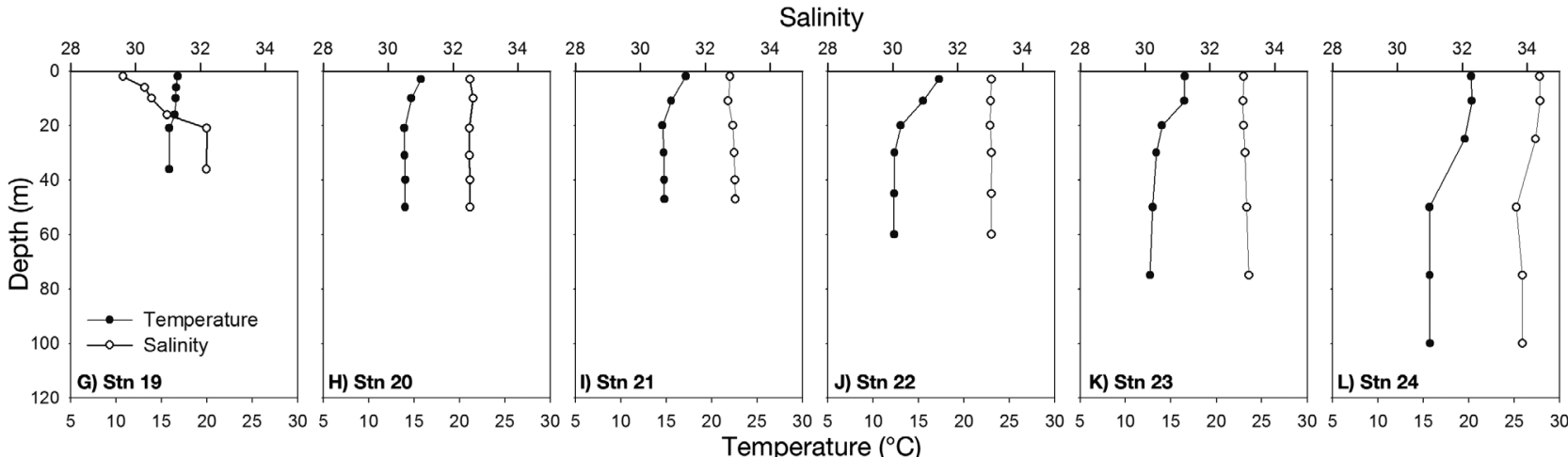

Fig. 3. Vertical profiles of $(\mathrm{A}-\mathrm{F})$ haptophyte abundance $\left(10^{2}\right.$ cells $\left.\mathrm{ml}^{-1}\right)$ and chlorophyll a (chl a) $\left(\mathrm{mg} \mathrm{m}^{-3}\right)$ as well as $(\mathrm{G}-\mathrm{L})$ temperature $\left({ }^{\circ} \mathrm{C}\right.$ ) and salinity along the north transect of Stns 19 to 24 during the spring cruise 
haptophyte abundance peaked at the surface, and then decreased with depth (Fig. 3). Chl a concentrations peaked at the surface in the more coastal water of Stns 19 and 20, where the distribution was similar to that of haptophytes, but peaked in the subsurface $(\sim 10$ to $20 \mathrm{~m})$ in the more oceanic water of Stns 21 to 23 (Fig. 3).

\section{Haptophyte cell size}

Haptophyte cell size in the ECS ranged from 2 to $9 \mu \mathrm{m}$, with averages of $3.5 \pm 0.5$ [SD] $\mu \mathrm{m}$ in spring and $3.1 \pm 0.4 \mu \mathrm{m}$ in summer. The average haptophyte size at each station varied from 2.7 to $5.0 \mu \mathrm{m}$ in spring and 2.2 to $3.9 \mu \mathrm{m}$ in summer. In spring, haptophytes with an average size of $>4 \mu \mathrm{m}$ appeared on the coast (Stns 18, 19 and 30) and middle shelf (Stns 15 and 16). However, in the summer, no station had haptophytes with an average size of $>4 \mu \mathrm{m}$, and those between 3.5 and $4.0 \mu \mathrm{m}$ appeared mostly near the areas of the CDW (Stns 19, 19A, 21-23 and 40-43) and the coast (Stn 4). Correlation analysis revealed that haptophyte cell size was positively associated with dissolved oxygen, $\mathrm{NO}_{3}, \mathrm{SiO}_{3}$ and chl a concentrations, and negatively with temperature, salinity and transparency (details of correlation coefficients and $\mathrm{p}$ values are shown in Table 2).

\section{S rRNA gene phylogeny of haptophytes}

Stns 12, 19 and 23 showed unique hydrographic conditions (Lin et al. 2012), and were selected to construct 18S rRNA gene clone libraries. A higher percentage of haptophyte sequences, $9 \%$ (5/53), was retrieved from Stn 23 in spring, reflecting the high relative abundance of haptophytes there. However, no haptophyte sequences were retrieved from the offshore water of Stn 12 in spring or from the coastal water of Stn 19 in summer.

By using a haptophyte-specific probe to screen about 400 clones randomly picked from the eukaryotic 18S rRNA gene libraries of Stn 16, 11 chimeric sequences were excluded, and a total of 24 accurate full-length haptophyte 18S rRNA sequences were retrieved. The haptophyte sequences from Stn 16 during the spring bloom contained 13 sequences of Phaeocystis, 6 sequences of Chrysochromulina, 4 sequences of Haptolina and 1 sequence of Prymnesiales. The Phaeocystis sequences were affiliated with P. cordata and P. jahnii, with identities from 98.5 to $99.4 \%$ and from 97.8 to $98.1 \%$, respectively. Phy-
Table 2. Pearson's correlations (r) were performed between haptophyte cell size and environmental variables in surface water in spring $(n=32)$ and summer $(n=47)$, respectively. Values marked with asterisks were considered significant, ${ }^{* *} \mathrm{p}<0.01$ or ${ }^{* * *} \mathrm{p}<0.001$

\begin{tabular}{|c|c|c|}
\hline \multirow[t]{2}{*}{ Variables } & \multicolumn{2}{|c|}{ Cell size } \\
\hline & Spring & Summer \\
\hline Temperature $\left({ }^{\circ} \mathrm{C}\right)$ & $-0.457^{* *}$ & $-0.463^{* *}$ \\
\hline Salinity & $-0.690^{* * *}$ & $-0.463^{* *}$ \\
\hline Transparency (\%) & $-0.579^{* *}$ & $-0.455^{* *}$ \\
\hline Dissolved oxygen $(\mu \mathrm{M})$ & $0.669^{* * *}$ & $0.575^{* * *}$ \\
\hline $\mathrm{NH}_{4}(\mu \mathrm{M})$ & 0.248 & 0.086 \\
\hline $\mathrm{NO}_{2}(\mu \mathrm{M})$ & 0.324 & 0.272 \\
\hline $\mathrm{NO}_{3}(\mu \mathrm{M})$ & $0.584^{* * *}$ & 0.156 \\
\hline $\mathrm{PO}_{4}(\mu \mathrm{M})$ & 0.298 & 0.283 \\
\hline $\mathrm{SiO}_{3}(\mu \mathrm{M})$ & $0.609^{* * *}$ & $0.458^{* *}$ \\
\hline Chlorophyll a $\left(\mathrm{mg} \mathrm{m}^{-3}\right)$ & $0.540^{* *}$ & $0.583^{* * *}$ \\
\hline
\end{tabular}

logenetic analysis showed that the sequences related to $P$. cordata and P. jahnii in the ECS were somewhat distinct from the cultured representatives, particularly those affiliated to P. jahnii (Fig. 4).

The partial sequences of the 18S rRNA gene were amplified with a specific primer pair. In total, 36 and 40 accurate sequences were obtained from spring and summer samples, respectively. All sequences belonged to haptophytes. In spring, Phaeocystis accounted for $42 \%$ of the total, with Prymnesium being the second largest contributor, accounting for $25 \%$. In summer, Chrysochromulina was the dominant component (33\%) (Table 3). Phylogenetic analysis showed that in spring some Phaeocystis sequences in the ECS affiliated to a clone retrieved from symbiotic Phaeocystis in Acantharia of the West Pacific Ocean (Fig. 5). Some Phaeocystis sequences from the ECS were affiliated to $P$. cordata, which was consistent with the results from full-length analysis. In this study, these Phaeocystis sequences were defined as $P$. jahnii-like and P. cordata-like. Most Phaeocystis and Haptolina sequences were acquired from spring samples, whereas most Chrysochromulina sequences were acquired in the summer (Fig. 5, Table 3).

\section{DISCUSSION}

Haptophytes can be ascribed to either pico- or nanosize fractions (Cuvelier et al. 2010, Masquelier et al. 2011). Preservation with formaldehyde can shrink cells, and therefore the size of haptophytes in our study may be underestimated (Choi \& Stoecker 1989). In this study, we regarded haptophytes as nanoplankton due to their observed size range of 2 to 
$9 \mu \mathrm{m}$. Previous studies have reported that haptophytes account for nearly half of the picophytoplankton carbon biomass at high latitudes in the Atlantic and Pacific oceans (Cuvelier et al. 2010), and contribute $38 \%$ of the eukaryotic abundance in the Atlantic water mass of the English Channel (Masquelier et al. 2011). In our study, haptophytes were detected at every station in the ECS (58 to 22392 cells $\mathrm{ml}^{-1}$ ), and overall contributed $32 \%$ and $12 \%$ to the abundances of total nanoflagellates (cells $\mathrm{ml}^{-1}$ ) in spring and summer, respectively. These results indicate that haptophytes are ubiquitous and an important component of eukaryotic phytoplankton in various marine ecosystems.
Even though the hydrographic conditions in the ECS are highly dynamic, the major water masses that occupy the ECS in the spring (SMW and YSMW) and summer (TCWW and CDW) were simply characterized using the salinity and temperature criteria defined by Gong et al. (1996) and Chiang et al. (2002) (Fig. 2). In spring, high numbers of haptophyte cells were observed in the YSMW (Fig. 2). Moreover, haptophyte abundance was negatively correlated with temperature in spring $(\mathrm{r}=-0.53, \mathrm{p}<$ 0.01 ), but did not correlate with nutrients. This suggests that the high abundance of haptophytes is driven by cold water in spring in the ECS. During summer, the haptophyte abundance peaked near

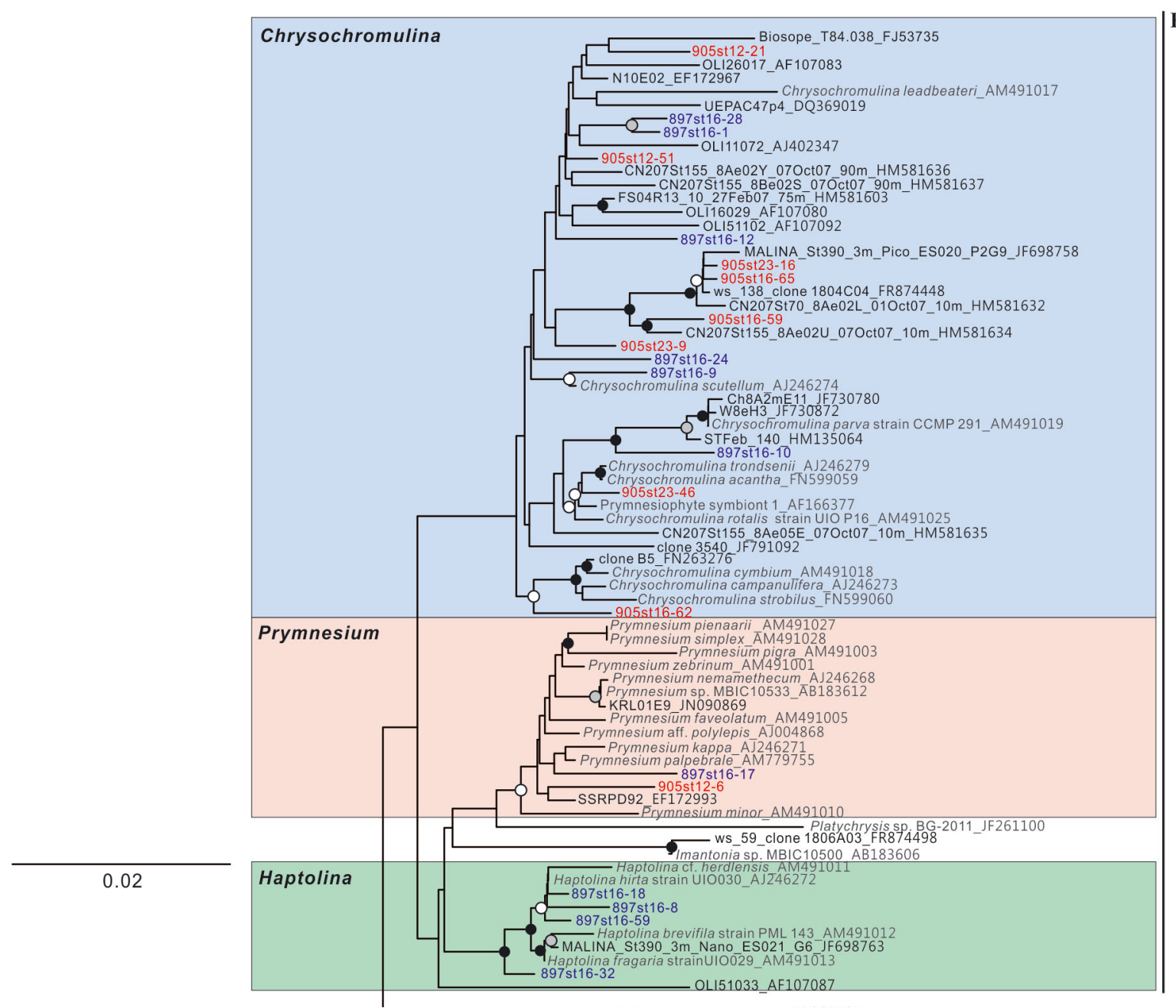

Prymnesiales

Fig. 4. Haptophyte phylogeny constructed using neighbor-joining with near-full length 18S rRNA gene sequences. A total of 1399 bp alignment positions were analyzed using maximum likelihood (ML) and neighbor-joining (NJ) methods with 1000 and 100 bootstraps, respectively. Only nodes with $>70 \%$ support are shown; filled circles indicate significant support by both ML

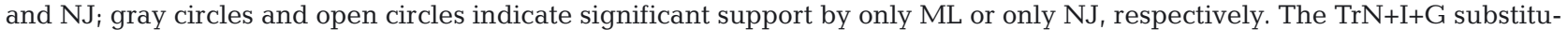
tion model ( $\mathrm{I}=0.316$ and $\alpha=0.487$ ) was used and Micromonas pusilla (AY954997), Rhodomonas salina (EU926158), Thalassiosira pseudonana (DQ093367) serve as an outgroup. The scale bar represents 0.02 nucleotide changes per position. The names of the East China Sea clones contain the cruise numbers (897, spring; 905, summer) and station numbers (Stn 12, 16, 19 or 23). The blue and red sequences represent spring and summer clones, respectively. Cultured or identified sequences are in gray and the environmental sequences are in black 


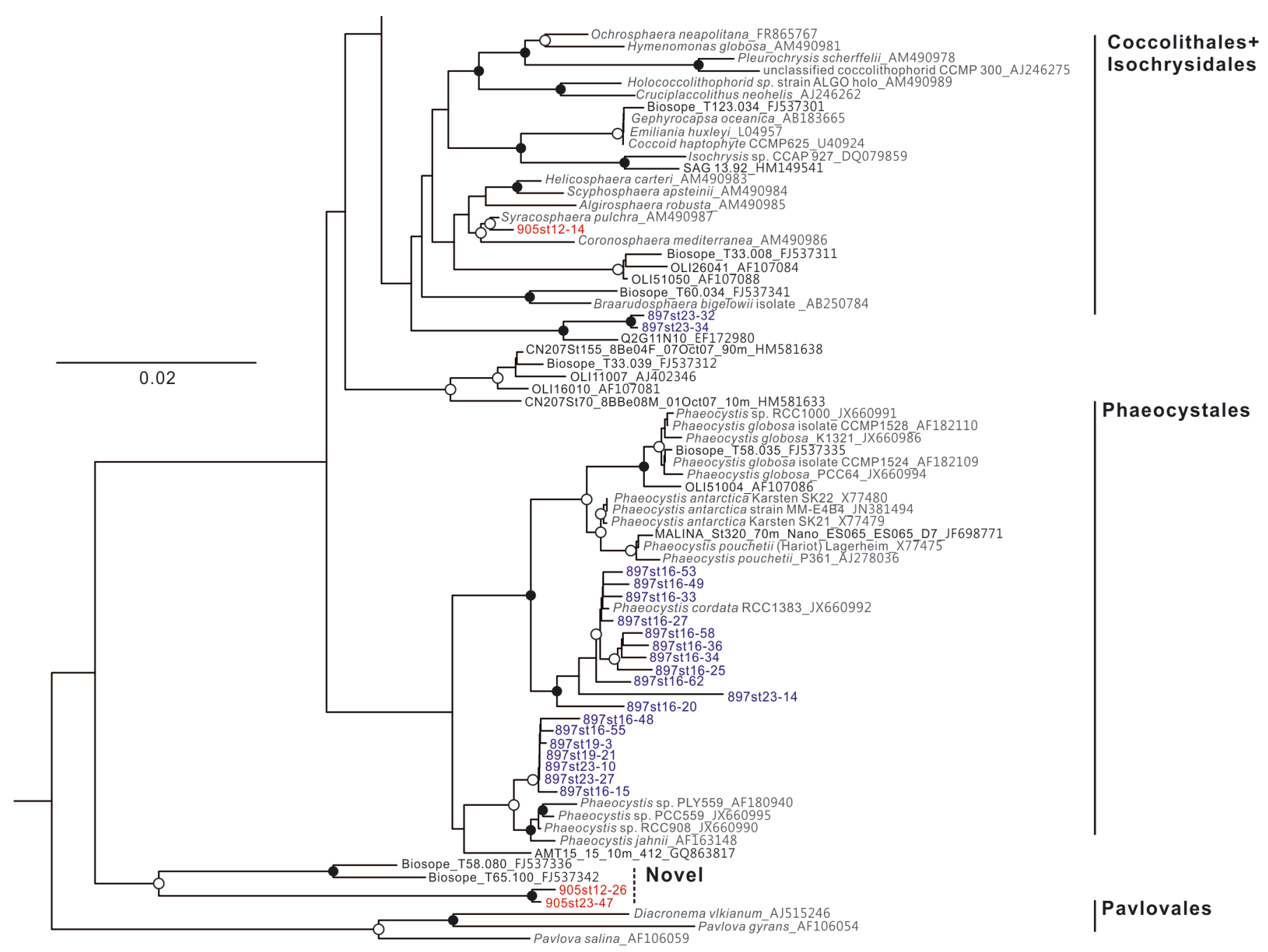

Fig. 4 (continued)

the edge of CDW (salinity $\sim 31$; Fig 2 ). These results imply that during our study period the Changjiang plume was an area of high nutrients but low light, whereas the edge of the CDW had a sufficiency of both resources (Zhu et al. 2009).

Phaeocystis is the dominant genus in spring in the ECS according to 18S rRNA gene data (Figs. 4 \& 5, Table 3). The large haptophytes $(>4 \mu \mathrm{m})$ found in coastal water (Stns 18, 19 and 30) and the middle shelf (Stns 15 and 16) may therefore consist of Phaeocystis. Overall, haptophyte cell sizes were smaller in summer than in spring ( $t$-test, $\mathrm{p}<0.001)$ and the average sizes in summer were all $<4 \mu \mathrm{m}$. The results of correlation analysis suggest that the level of eutrophication influences haptophyte cell size in both spring and summer (Table 2). This lends support to the idea that small phytoplankton with a high surfacevolume ratio have an advantage over other phytoplankton in oligotrophic conditions in the competi- tion for nutrients (Raven 1998). In addition, a positive relationship between cell size and haptophyte abundance implies that the types of haptophyte tend to be those with a larger cell size in bloom conditions ( $\mathrm{r}=0.36, \mathrm{p}<0.01)$.

In addition to the large number of Phaeocystis sequences discovered in spring, Chrysochromulina was also an important component in the ECS (Figs. 4 \& 5, Table 3). This is consistent with previous research based on studies of 28S rRNA and 18S rRNA genes that showed that Chrysochromulina contributes a large proportion of haptophytes in the open ocean (Liu et al. 2009, Cuvelier et al. 2010). With respect to the phylogeny of the 18S rRNA gene, the high diversity detected in Chrysochromulina implies that some of the genetic clades do not have a cultured representative (Fig. 4). Moreover, some novel haptophyte sequences located at the base of the phylogenetic tree, including 2 sequences reported here 
Table 3. Clone numbers for different taxonomic groups of haptophytes at Stn 16 found by using specific primers to amplify the 18S rRNA gene. A total of 36 and 40 sequences were obtained in the spring and summer, respectively. The number in parentheses represents the percentage of total haptophyte sequences

\begin{tabular}{|c|c|c|c|c|c|c|}
\hline Seasons & Clone numbers & Haptolina & Prymnesium & Chrysochromulina & Phaeocystis & Others \\
\hline Spring & 36 & $7(19 \%)$ & $9(25 \%)$ & $5(14 \%)$ & $15(42 \%)$ & $0(0 \%)$ \\
\hline Summer & 40 & $4(10 \%)$ & $4(10 \%)$ & $13(33 \%)$ & $8(20 \%)$ & $11(28 \%)$ \\
\hline
\end{tabular}

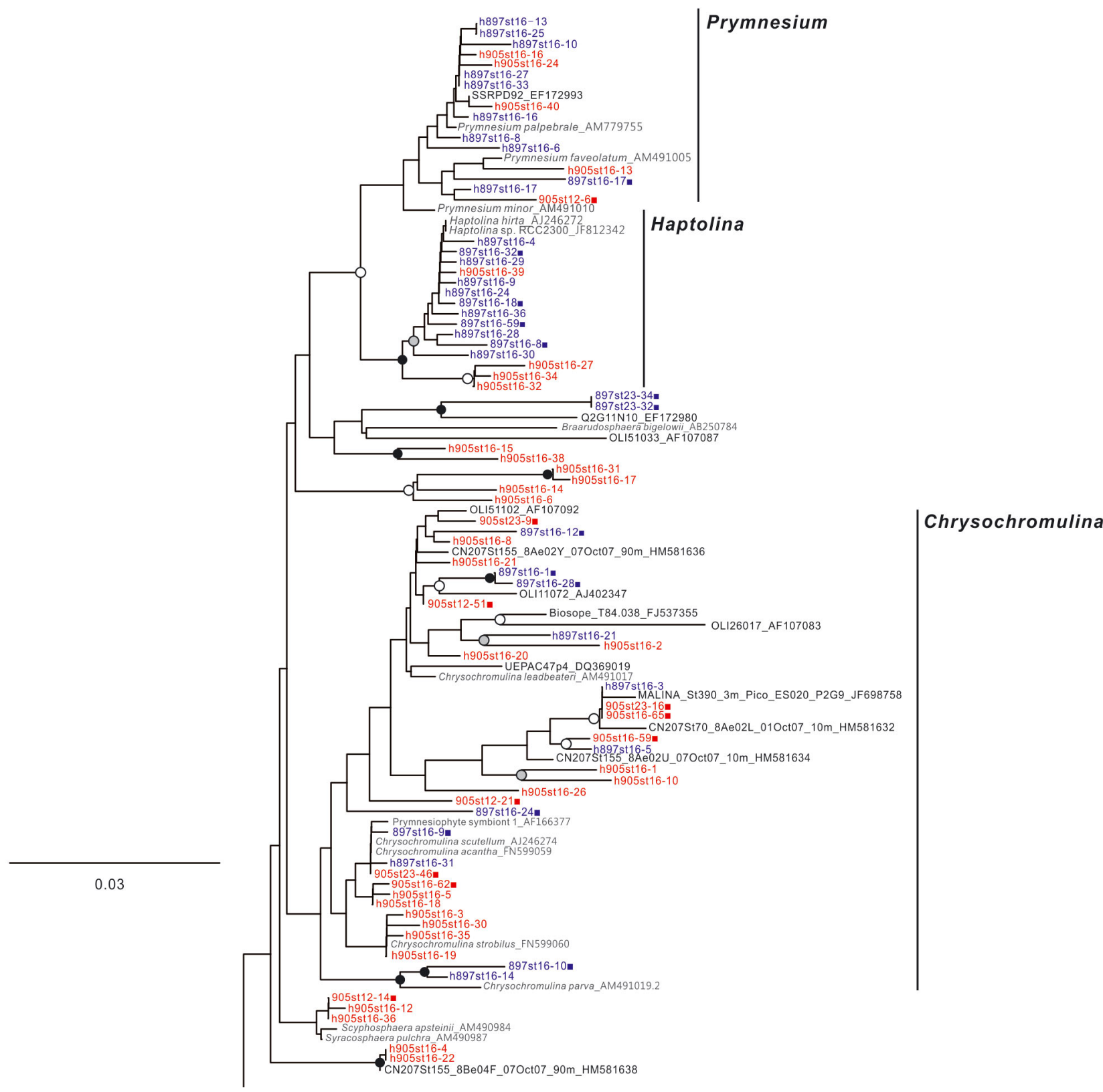

Fig. 5. Haptophyte phylogeny constructed using neighbor-joining with partial length 18S rRNA gene sequences. A total of $449 \mathrm{bp}$ alignment positions were analyzed using maximum likelihood (ML) and neighbor-joining (NJ) methods with 1000 and 100 bootstraps, respectively. Only nodes with $>70 \%$ support are shown; filled circles indicate significant support by both ML

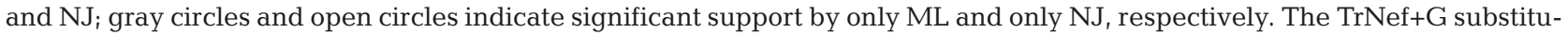
tion model used $(\alpha=0.473)$ and outgroup was as for Fig. 4 . The scale bar represents 0.03 nucleotide changes per position. The filled squares represent the full-length sequences also shown in Fig. 4 


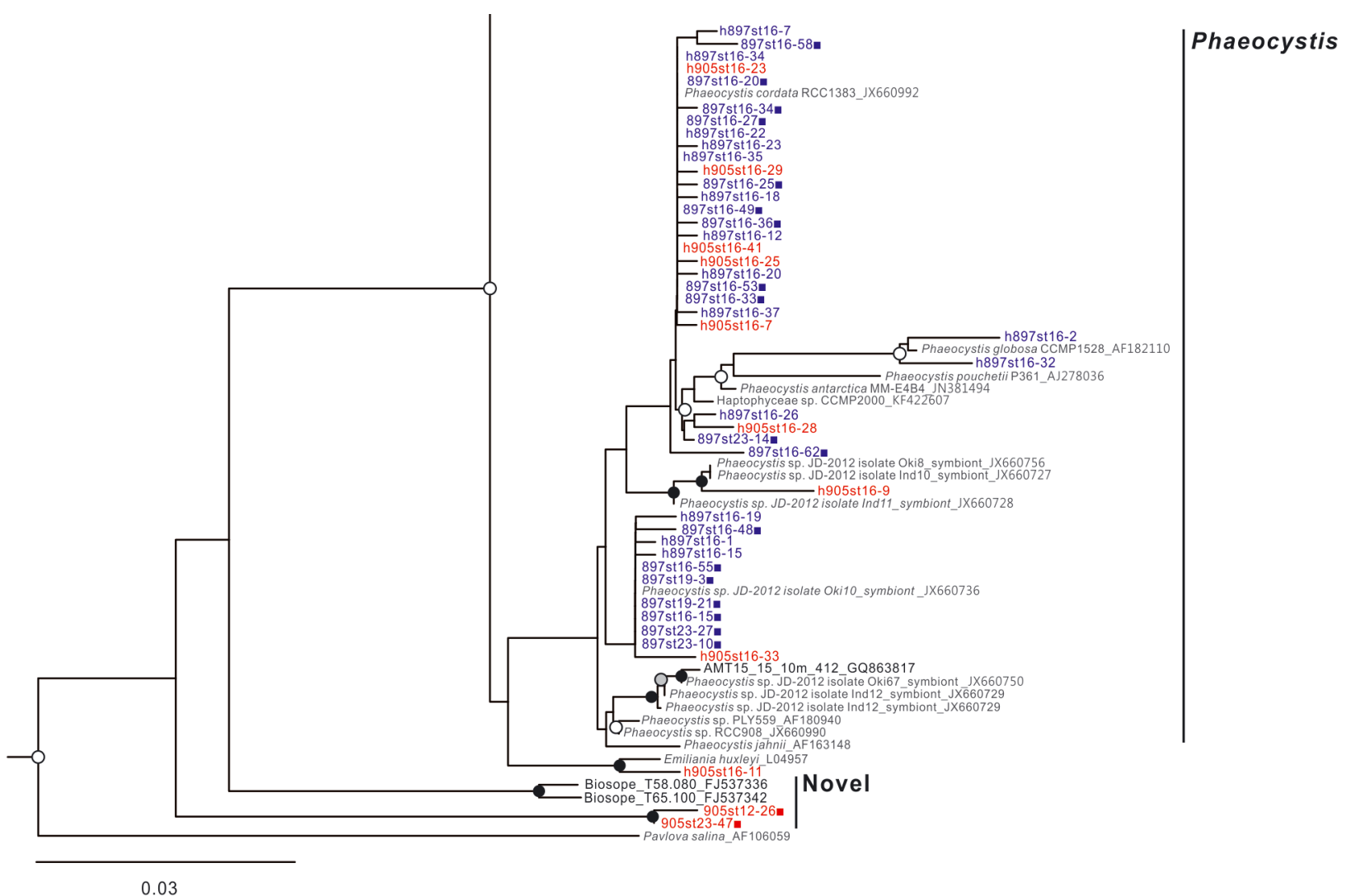

Fig. 5 (continued)

and 2 environmental sequences (Biosope_T58.080 and Biosope_T65.100) from the South East Pacific Ocean (Fig. 4), confirm the extensive phylogenetic diversity and novelty of haptophytes in the world's oceans (Shi et al. 2009).

The haptophyte bloom was observed in the YSMW during spring, and approximately half of the haptophyte sequences belonged to Phaeocystis at Stn 16 (Table 3). Phaeocystis sequences were also retrieved from the coastal water and continental shelf water (Stns 16, 19 and 23; Figs. 4 \& 5), confirming it as the dominant genus in the ECS during spring. Large numbers of Phaeocystis sequences were retrieved from the spring samples, but only a few were obtained from the summer samples (Table 3). Previous studies have indicated that Phaeocystis is a spring-bloom genus, particularly at high latitudes (DiTullio et al. 2000, Monchy et al. 2012, Vogt et al. 2012). P. pouchetii and $P$. antarctica are well-known bloom species occurring in polar areas, and P. globosa is prevalent from tropical to temperate areas (Schoemann et al. 2005, Monchy et al. 2012, Vogt et al. 2012, Rousseau et al. 2013). In our study, the Phaeocystis sequences from the ECS were related to $P$. jahnii and $P$. cordata, both originally found in
Mediterranean water. Scanning electron microscopy inspection of the FISH filter at Stn 16 revealed no colonies of Phaeocystis, but pentagonal stars of Phaeocystis and heart-shaped $P$. cordata-like cells were found (data not shown). Cells on a filter preserved with a high concentration of formaldehyde may dissolve colonies, making their detection difficult. Until now, all of the sequences affiliated to $P$. jahnii and $P$. cordata have been retrieved from latitudes between 10 and $45^{\circ}$. A recent study on the phylogeny of the symbiotic relationship between Phaeocystis and Acantharia demonstrated that genetic distances of symbiont Phaeocystis were significantly correlated to its biogeography, but had no relationship with the host taxonomy (Decelle et al. 2012). Overall, our results are consistent with previous studies showing that species of Phaeocystis occurring in polar and non-polar areas are distinct (Schoemann et al. 2005, Decelle et al. 2012). Few studies have reported blooms of $P$. jahnii and $P$. cordata, which may be due to their small size, or may indicate that they cannot form, or seldom form, colonies in the natural environment (Zingone et al. 1999, Medlin \& Zingone 2007). Molecular approaches appear to be useful tools for studying the distributions of $P$. jahnii and P. cordata. 
Temperature may be an important factor in controlling the distribution of $P$. jahnii and $P$. cordata during spring in the ECS. Laboratory studies indicate that the optimal temperature for the maximum growth rate of Phaeocystis is around $16^{\circ} \mathrm{C}$ (Schoemann et al. 2005). A large number of $16 \mathrm{~S}$ rRNA gene sequences related to $P$. jahnii and $P$. cordata were simultaneously retrieved from spring samples in the Gulf of Naples, implying either an unknown relationship or that they are controlled by the same resources. The temperature in the Gulf of Naples at that time was around $15^{\circ} \mathrm{C}$, similar to that of our spring sampling (McDonald et al. 2007). Our study indicated that peak haptophyte abundance occurred at $15.7^{\circ} \mathrm{C}$ in spring, and 18S rRNA gene data showed that Phaeocystis was the dominant genus (Figs. 2, 4 \& 5). Zingone et al. (1999) stated that the presence of Phaeocystis in the Gulf of Naples cannot be attributed to temperature because they also appear in autumn when the temperature exceeds $23^{\circ} \mathrm{C}$. Moreover, the environmental clones related to $P$. jahnii retrieved from the Indian and Atlantic oceans (IND58.21 and AMT15_15_10m_412) came from warm waters $\left(>25^{\circ} \mathrm{C}\right)$ (Not et al. 2008, Kirkham et al. 2011). However, no study has ever reported that Phaeocystis thrives in high-temperature water.

Previous studies have demonstrated that a Phaeocystis bloom is induced by nitrate excess (Breton et al. 2006), whereas a diatom bloom is controlled by silicate (Rousseau et al. 2002). Moreover, when silicate was at low concentration, the Phaeocystis bloom appeared after the diatom bloom (Egge \& Aksnes 1992). Contrary to expectations, in our study the highest numbers of haptophytes were observed in waters with a high concentration of silicate $(\sim 8 \mu \mathrm{M})$, but a low level of nitrate and phosphate $(0.3 \mu \mathrm{M}$ and $0.06 \mu \mathrm{M}$, respectively). In the ECS, the concentration of phosphate was significantly lower in spring than in summer (paired $t$-test, $\mathrm{p}<0.01$; Table 1). Although diatom abundance was not measured in our study, it is generally high in the ECS during spring (Furuya et al. 2003). Our study suggests that the concentrations of $\mathrm{N}$ and $\mathrm{P}$ are not critical restricting factors in the distribution of haptophytes in spring in the ECS. With regard to the profile data, peak haptophyte abundance occurred in surface water, indicating that irradiance plays a crucial role in their vertical distribution (Fig. 3). A recent study reported that some Phaeocystis have a symbiotic relationship with Acantharia (Decelle et al. 2012). The clone libraries from our samples were constructed from $<5 \mu \mathrm{m}$ size fractions, which may have excluded Acantharia sequences. Phylogenetic analysis of partial sequences revealed that a number of Phaeocystis sequences in the ECS were identical or related to a sequence retrieved from symbiont Phaeocystis which has been found off Japan (Fig. 5). A symbiotic relationship might be beneficial for Phaeocystis, enabling them to escape nutrient limitation by obtaining nutrition from their hosts. However, in our study, it was difficult to study the symbiotic relationship of Phaeocystis by observing the FISH slides. Our data suggests that, in the ECS spring, temperature plays a crucial role in controlling haptophyte abundance. Overall, the distribution and diversity of haptophytes in the ECS varied dramatically with seasonal water masses.

\section{CONCLUSIONS}

This study reported a haptophyte bloom event during the spring in a subtropical system of the northwestern Pacific Ocean. Overall, the biomass of haptophytes in the ECS ranged from 1 to $194 \mu \mathrm{g} \mathrm{l^{-1 }}$ in spring and 0.09 to $21 \mathrm{\mu g}^{-1}$ in summer. A high level of haptophyte abundance appeared in the YSMW in spring, of which 18S rRNA genes were affiliated with Phaeocystis jahnii and $P$. cordata. The peak of haptophyte abundance occurred at the boundary between coastal mixing water and oceanic water, and also at the station with the lowest temperature in the spring. We do not know whether the high level of haptophytes was due to their being brought in by Yellow Sea currents, or whether they simply thrived in the favorable environment in the ECS during spring. However, future studies in the ECS should look at the fate of carbon and sulfur produced by haptophytes in spring as they make up a large part of total nanoplankton.

Acknowledgements. We thank the captain and crew of RV 'Ocean Researcher I'. We also are grateful to Ciou-Jyu Wang for the counting of nanoplankton and Ya-Fan Chan for the inspection of the filter at Stn 16 with a scanning electron microscope. This research was supported by the National Science Council, Taiwan (NSC98-2611-M-019-021-MY3).

\section{LITERATURE CITED}

Breton E, Rousseau V, Parent JY, Ozer J, Lancelot C (2006) Hydroclimatic modulation of diatom/Phaeocystis blooms in nutrient-enriched Belgian coastal waters (North Sea). Limnol Oceanogr 51:1401-1409

Chiang KP, Chen YT, Gong GC (1999) Spring distribution of diatom assemblages in the East China Sea. Mar Ecol Prog Ser 186:75-86

Chiang KP, Kuo MC, Chang J, Wang RH, Gong GC (2002) Spatial and temporal variation of the Synechococcus population in the East China Sea and its contribution to phytoplankton biomass. Cont Shelf Res 22:3-13 
Choi JW, Stoecker DK (1989) Effects of fixation on cell volume of marine planktonic protozoa. Appl Environ Microbiol 55:1761-1765

Chung CC, Hwang SPL, Chang J (2003) Identification of a high-affinity phosphate transporter gene in a prasinophyte alga, Tetraselmis chui, and its expression under nutrient limitation. Appl Environ Microbiol 69:754-759

> Chung CC, Huang CY, Gong GC, Lin YC (2014) Influence of the Changjiang River flood on Synechococcus ecology in the surface waters of the East China Sea. Microb Ecol 67: 273-285

> Coolen MJ, Muyzer G, Rijpstra WIC, Schouten S, Volkman JK, Sinninghe Damsté JS (2004) Combined DNA and lipid analyses of sediments reveal changes in Holocene haptophyte and diatom populations in an Antarctic lake. Earth Planet Sci Lett 223:225-239

> Cuvelier ML, Allen AE, Monier A, McCrow JP and others (2010) Targeted metagenomics and ecology of globally important uncultured eukaryotic phytoplankton. Proc Natl Acad Sci USA 107:14679-14684

> Dagg M, Benner R, Lohrenz S, Lawrence D (2004) Transformation of dissolved and particulate materials on continental shelves influenced by large rivers: plume processes. Cont Shelf Res 24:833-858

> Decelle J, Probert I, Bittner L, Desdevises Y and others (2012) An original mode of symbiosis in open ocean plankton. Proc Natl Acad Sci USA 109:18000-18005

> DiTullio GR, Grebmeier JM, Arrigo KR, Lizotte MP and others (2000) Rapid and early export of Phaeocystis antarctica blooms in the Ross Sea, Antarctica. Nature 404: 595-598

Egge JK, Aksnes DL (1992) Silicate as regulating nutrient in phytoplankton competition. Mar Ecol Prog Ser 83: 281-289

Felsenstein J (2005) PHYLIP (phylogeny inference package) version 3.68, http://evolution.genetics.washington.edu/ phylip.html

> Furuya K, Hayashi M, Yabushita Y, Ishikawa A (2003) Phytoplankton dynamics in the East China Sea in spring and summer as revealed by HPLC-derived pigment signatures. Deep-Sea Res II 50:367-387

> Gong GC, Liu KK, Pai SC (1995) Prediction of nitrate concentration from two end member mixing in the southern East China Sea. Cont Shelf Res 15:827-842

Gong GC, Lee Chen YL, Liu KK (1996) Chemical hydrography and chlorophyll a distribution in the East China Sea in summer: implications in nutrient dynamics. Cont Shelf Res 16:1561-1590

Gong GC, Liu KK, Chiang KP, Hsiung TM and others (2011) Yangtze River floods enhance coastal ocean phytoplankton biomass and potential fish production. Geophys Res Lett 38, L13603, doi:10.1029/2011GL047519

> Jardillier L, Zubkov MV, Pearman J, Scanlan DJ (2010) Significant $\mathrm{CO}_{2}$ fixation by small prymnesiophytes in the subtropical and tropical northeast Atlantic Ocean. ISME J 4:1180-1192

Kirkham AR, Jardillier LE, Tiganescu A, Pearman J, Zubkov MV, Scanlan DJ (2011) Basin scale distribution patterns of photosynthetic picoeukaryotes along an Atlantic Meridional Transect. Environ Microbiol 13: 975-990

Lancelot C, Mathot S (1987) Dynamics of a Phaeocystisdominated spring bloom in Belgian coastal waters. I. Phytoplanktonic activities and related parameters. Mar Ecol Prog Ser 37:239-248
Lin YC, Campbell T, Chung CC, Gong GC, Chiang KP, Worden AZ (2012) Distribution patterns and phylogeny of marine stramenopiles (MAST) in the North Pacific Ocean. Appl Environ Microbiol 78:3387-3399

> Liss P, Malin G, Turner S, Holligan P (1994) Dimethyl sulphide and Phaeocystis: a review. J Mar Syst 5:41-53

> Liu H, Probert I, Uitz J, Claustre H, Aris-Brosou S, Frada M (2009) Extreme diversity in noncalcifying haptophytes explains a major pigment paradox in open oceans. Proc Natl Acad Sci USA 106:12803-12808

Masquelier S, Foulon E, Jouenne F, Ferréol M, Brussaard CPD, Vaulot D (2011) Distribution of eukaryotic plankton in the English Channel and the North Sea in summer. J Sea Res 66:111-122

> Massana R, Guillou L, Terrado R, Forn I, Pedrós-Alió C (2006) Growth of uncultured heterotrophic flagellates in unamended seawater incubations. Aquat Microb Ecol 45:171-180

McDonald SM, Sarno D, Scanlan DJ, Zingone A (2007) Genetic diversity of eukaryotic ultraphytoplankton in the Gulf of Naples during an annual cycle. Aquat Microb Ecol 50:75-89

> Medlin L, Zingone A (2007) A taxonomic review of the genus Phaeocystis. Biogeochemistry 83:3-18

> Medlin L, Elwood HJ, Stickel S, Sogin ML (1988) The characterization of enzymatically amplified eukaryotic 16Slike rRNA-coding regions. Gene 71:491-499

> Monchy S, Grattepanche JD, Breton E, Meloni D and others (2012) Microplanktonic community structure in a coastal system relative to a Phaeocystis bloom inferred from morphological and tag pyrosequencing methods. PLoS ONE 7:e39924

> Moon-Van der Staay SY, van der Staay GWM, Guillou L, Vaulot D, Claustre H, Medlin LK (2000) Abundance and diversity of prymnesiophytes in the picoplankton community from the equatorial Pacific Ocean inferred from 18S rDNA sequences. Limnol Oceanogr 45:98-109

> Morris A, Riley J (1963) The determination of nitrate in sea water. Anal Chim Acta 29:272-279

> Not F, Simon N, Biegala IC, Vaulot D (2002) Application of fluorescent in situ hybridization coupled with tyramide signal amplification (FISH-TSA) to assess eukaryotic picoplankton composition. Aquat Microb Ecol 28: 157-166

Not F, Latasa M, Scharek R, Viprey M and others (2008) Protistan assemblages across the Indian Ocean, with a specific emphasis on the picoeukaryotes. Deep-Sea Res II 55:1456-1473

Pai SC, Yang CC (1990) Formation kinetics of the pink azo dye in the determination of nitrite in natural waters. Anal Chim Acta 232:345-349

Parsons TR, Maita Y, Lalli CM (1984) A manual of chemical and biological methods for seawater analysis. Pergamon Press, Oxford

> Porter KG, Feig YS (1980) The use of DAPI for identifying and counting aquatic microflora. Limnol Oceanogr 25: 943-948

> Posada D (2008) jModelTest: phylogenetic model averaging. Mol Biol Evol 25:1253-1256

> Raven J (1998) The twelfth Tansley Lecture. Small is beautiful: the picophytoplankton. Funct Ecol 12:503-513

Rousseau V, Leynaert A, Daoud N, Lancelot C (2002) Diatom succession, silicification and silicic acid availability in Belgian coastal waters (Southern North Sea). Mar Ecol Prog Ser 236:61-73 
Rousseau V, Lantoine F, Rodriguez F, LeGall F, ChrétiennotDinet MJ, Lancelot C (2013) Characterization of Phaeocystis globosa (Haptophyceae), the blooming species in the Southern North Sea. J Sea Res 76:105-113

Schoemann V, Becquevort S, Stefels J, Rousseau V, Lancelot C (2005) Phaeocystis blooms in the global ocean and their controlling mechanisms: a review. J Sea Res 53: 43-66

Shi XL, Marie D, Jardillier L, Scanlan DJ, Vaulot D (2009) Groups without cultured representatives dominate eukaryotic picophytoplankton in the oligotrophic South East Pacific Ocean. PLoS ONE 4:e7657

Simon N, Campbell L, Örnolfsdottir E, Groben R, Guillou L, Lange M, Medlin LK (2000) Oligonucleotide probes for the identification of three algal groups by dot blot and fluorescent whole-cell hybridization. J Eukaryot Microbiol 47:76-84

Tang DL, Di BP, Wei G, Ni IH, Oh IS, Wang SF (2006) Spatial, seasonal and species variations of harmful algal blooms in the South Yellow Sea and East China Sea. Hydrobiologia 568:245-253

Vaulot D, Eikrem W, Viprey M, Moreau H (2008) The diversity of small eukaryotic phytoplankton $(\leq 3 \mu \mathrm{m})$ in marine

Editorial responsibility: Daniel Vaulot, Roscoff, France ecosystems. FEMS Microbiol Rev 32:795-820

> Vogt M, O'Brien C, Peloquin J, Schoemann V and others (2012) Global marine plankton functional type biomass distributions: Phaeocystis spp. Earth Syst Sci Data 4: 107-120

Worden AZ (2006) Picoeukaryote diversity in coastal waters of the Pacific Ocean. Aquat Microb Ecol 43:165-175

- Worden AZ, Nolan JK, Palenik B (2004) Assessing the dynamics and ecology of marine picophytoplankton: the importance of the eukaryotic component. Limnol Oceanogr 49: 168-179

> Zhou M, Shen Z, Yu R (2008) Responses of a coastal phytoplankton community to increased nutrient input from the Changjiang (Yangtze) River. Cont Shelf Res 28:1483-1489

> Zhu ZY, Ng WM, Liu SM, Zhang J, Chen JC, Wu Y (2009) Estuarine phytoplankton dynamics and shift of limiting factors: a study in the Changjiang (Yangtze River) Estuary and adjacent area. Estuar Coast Shelf Sci 84:393-401

Zingone A, Chrétiennot-Dinet MJ, Lange M, Medlin L (1999) Morphological and genetic characterization of Phaeocystis cordata and P. jahnii (Prymnesiophyceae), two new species from the Mediterranean Sea. J Phycol 35:1322-1337

Submitted: September 12, 2013; Accepted: March 27, 2014 Proofs received from author(s): May 12, 2014 